\title{
Androgen Receptor Expression and Function in Osteoclasts
}

\author{
A.G. Turner ${ }^{1}$, A.J. Notini ${ }^{1}$, W.S.M. Chiu ${ }^{1}$, J. Hodge ${ }^{2}$, G. Nicholson ${ }^{2}$, J.D. Zajac ${ }^{1}$ and R.A. Davey*,1 \\ ${ }^{I}$ Department of Medicine, University of Melbourne, Austin Health, Studley Road, Heidelberg, Victoria, 3084, Australia, \\ ${ }^{2}$ University of Melbourne, Department of Clinical and Biomedical Sciences, Barwon Health, Geelong, Victoria, 3220, \\ Australia
}

\begin{abstract}
We assessed androgen receptor (AR) expression in osteoclasts in vitro and in situ. Rat multinucleated osteoclasts expressed detectable AR protein in situ, and AR mRNA was detected in mouse and human derived osteoclast-like cells in vitro. Dihydrotestosterone treatment did not affect human osteoclast-like cell formation or resorption in vitro.
\end{abstract}

Keywords: Androgen receptor, osteoclasts, bone resorption.

\section{INTRODUCTION}

It is well accepted that androgens are essential for skeletal growth and bone accrual during puberty and for bone maintenance post-puberty in males. Hypogonadism in men results in bone loss [1] and orchidectomy of male rats results in cortical and trabecular bone loss in the vertebrae, tibia and femur $[2,3]$ due to an imbalance between bone formation and bone resorption. This bone loss, associated with androgen deficiency in men and rodents can be prevented by treatment with either aromatizable or nonaromatizable androgens [3-5]. There is evidence that androgens mediate their effect via direct activation of the androgen receptor (AR) in osteoblasts. In support of this, the AR has been identified in human and rat osteoblast-like cells [6,7], normal human osteoblasts in vitro [8] and human and rat bone in situ [9-11]. Moreover, we have previously generated genetically modified mice in which the AR is specifically deleted within mature osteoblasts [12]. Inactivation of the AR specifically in mature osteoblasts of male mice led to increased bone resorption resulting in a reduction in trabecular bone volume of $17 \%$ compared to controls [12]. However it is also possible that androgens may inhibit bone resorption by inhibiting the formation and/or function of osteoclasts [13-15]. Whether this is achieved via direct actions of androgens on osteoclasts however remains controversial.

To date, AR expression in osteoclasts has been putatively identified using binding assays in $90 \%$ pure osteoclasts isolated from avian long bones [13] and by immunohistochemical localisation of AR protein in rat bone sections [11] and mouse osteoclast-like cells in vitro [16]. However the AR protein has not been detected in human osteoclasts in situ $[9$, $10]$.

A number of previous studies have attempted to investigate a potential role of androgens in regulating bone resorption by assessing androgen affects on osteoclast formation and activity. However these studies have generated conflict-

*Address correspondence to this author at the Department of Medicine, Austin Health, University of Melbourne, Level 7, Lance Townsend Building, Studley Road, Heidelberg, Victoria, 3084,Australia; Tel: 6139496 5507; Fax: 6139457 5485; E-mail: r.davey@unimelb.edu.au ing findings of either no effect $[17,18]$ or inhibition of osteoclast formation and bone resorption [13, 15, 19] following androgen treatment. Testosterone and/or DHT treatment have been shown to inhibit the formation of osteoclasts derived from bone marrow macrophages [15], RAW264.7 cells [15], peripheral blood mononuclear cells [14] and mouse bone osteoclast and osteoblast co-cultures [19] in vitro.

Non-aromatisable androgens have also been shown to inhibit the resorptive activity of isolated avian osteoclasts and human and mouse osteoclast-like cells in vitro $[13,14]$, an effect which must be via the AR. Furthermore, treatment of mouse osteoclast and osteoblast co-cultures in vitro with flutamide, a non-steroidal AR antagonist, reverses the inhibitory effect of testosterone on osteoclastic bone resorption [19], providing further supportive evidence for a direct action of androgens via the AR in osteoclasts. In contrast, a study by Tobias and Chambers [17] found that DHT had no effect on bone resorption activity of osteoclasts isolated from neonatal rats, cultured with or without osteoblast or osteoblast-like cells [17]. Interpretation of the previous studies investigating a direct action of androgens on bone resorption is complicated by the fact that many different models of osteoclastogenesis have been used, often involving a mixed population of cells that include osteoblasts, which are direct targets for androgen action. Furthermore, many studies have treated cells with testosterone which can potentially be aromatized to estradiol, a potent inhibitor of bone resorption in humans [20] and rodents [21].

In order to ascertain whether androgens act directly via the AR in osteoclasts to regulate bone resorption, the aim of this study was to firstly determine whether rat osteoclasts in situ express AR mRNA and protein. For this purpose, osteoclasts were defined as large, multinucleated cells, found within resorption pits in bone that had both tartrate-resistant acid phosphatase (TRAP) enzyme activity and calcitonin receptor (CTR) expression. Although technically simple to detect, TRAP, unlike the CTR, can not definitively identify mature osteoclasts as it is also expressed in activated macrophages [22]. The second aim of the study was to determine whether osteoclast-like cells derived from mouse and human precursors express AR mRNA in vitro and whether DHT 
treatment of these cells affects their formation and/ or function.

\section{MATERIALS AND METHODS}

\section{Animals}

Three-month old female Sprague-Dawley rats and C57BL/6J mice were obtained from the Animal Resource Centre, Canning Vale, WA, Australia. The animals were fed commercial mouse chow containing $0.7 \%$ calcium and $0.6 \%$ phosphorus (Ridley Agriproducts Pty. Ltd., Australia) and tap water was supplied ad libitum. The animals were housed at $24^{\circ} \mathrm{C}$ with a 12 hour light-dark cycle. The Austin Health Animal Ethics Committee approved all procedures.

\section{Specimen Preparation}

Rats were sacrificed by $\mathrm{CO}_{2}$ asphyxiation and femora and testes removed. All specimens were fixed in 4\% paraformaldehyde at $4{ }^{\circ} \mathrm{C}$ overnight. The femora were decalcified in $15 \%$ EDTA in $0.5 \%$ paraformaldehyde/DEPC-PBS, $\mathrm{pH} 8.0$, for 6-13 days, with fresh solution every 2-3 days. All specimens were processed, embedded in paraffin and $4 \mu \mathrm{m}$ midsagittal serial sections were cut.

\section{In Situ Hybridisation}

PCR primers to amplify a 578bp fragment of rat $A R$ cDNA, containing the $\mathrm{N}$-terminal region of the AR and part of the DNA-binding domain, were designed based on a previously published rat AR cDNA probe [23]. PCR was performed using rat kidney cDNA template, a high fidelity DNA polymerase with proofreading activity (Pfu DNA polymerase, Promega, Australia) and rat AR specific primers; Fwd: 5'-TCGCGACTACTACAACTTTCCG-3' and Rev: 5'AAGCTTCATCTCCACAG ATCAG-3'. The resulting product was subcloned into the host plasmid, pGEM-T (Promega, USA) using standard cloning techniques. Plasmid DNA was purified, sequenced and linearized by NcoI and NotI for antisense and sense control probes, respectively. [ $\alpha$ ${ }^{35}$ S-rCTP] labelled, single-stranded antisense and sense RNA probes were prepared and hydrolysed to $200 \mathrm{bp}$. Hybridisation using $5 \times 10^{5}$ c.p.m $/ \mu \mathrm{L}{ }^{35} \mathrm{~S}$-labelled riboprobe to histological sections and detection was performed as previously described [24].

\section{TRAP Staining}

TRAP enzyme activity was detected in paraffin-tissue sections and osteoclast cultures using an Acid Phosphatase Leukocyte Kit (Sigma Diagnostics, USA) according to the manufacturer's instructions.

\section{Immunohistochemistry}

Primary antibodies used for the immunohistochemistry studies are as follows: C-19 (Santa Cruz Biotechnology, USA): a specific polyclonal rabbit anti-human AR antibody which recognises the carboxyl terminus of the human AR and cross-reacts with the mouse AR and Anti-rat CTR (a kind gift from Dr Peter Wookey, Department of Medicine, Austin Health, The University of Melbourne, Australia): a specific polyclonal rabbit anti-rat CTR antibody. The CTR antibody was raised to a synthetic peptide corresponding to an epitope on the rat CTR, located in the cytoplasm and after the seventh transmembrane domain [25]. Immunohistochem- istry for AR and CTR was based on the method previously described by Kask et al. [26] using a horseradish peroxidase detection system. Sections were counter-stained with haematoxylin.

\section{Generation of Mouse Osteoclast-Like Cells}

Osteoclasts were derived from bone marrow isolated from the femora of $\mathrm{C} 57 \mathrm{BL} / 6 \mathrm{~J}$ mice as previously described [27]. Isolated bone marrow cells were cultured in $\alpha$ minimum essential medium ( $\alpha$-MEM) containing $10 \%$ fetal calf serum (FCS) and recombinant human macrophage colony-stimulating factor (M-CSF) $(100 \mathrm{ng} / \mathrm{mL})$. Cells were cultured for 3 days at $37^{\circ} \mathrm{C}$ in $5 \% \mathrm{CO}_{2}$, after which all nonadherent cells were removed by rinsing with PBS. Media was replaced with the addition of recombinant human receptor activator of nuclear factor $\kappa \mathrm{B}$-ligand (RANKL) (100 $\mathrm{ng} / \mathrm{mL}$ ) and MCSF at $50 \mathrm{ng} / \mathrm{mL}$, and the cells cultured for a further 4 days.

\section{Generation of Human Osteoclast-Like Cells}

Human umbilical cord blood was obtained from healthy donors using a procedure approved by Barwon Health Research and Ethics Advisory Committee. A mononuclear cell fraction containing monocytes and lymphocytes from cord blood was isolated and cultured for osteoclast precursor cells (colony forming unit-granulocyte macrophages (CFU-GM)) as described previously [28]. CFU-GM were seeded on $4 \mathrm{~mm}^{2}$ sperm whale dentine slices at concentration of $4 \times 10^{4}$ per slice per well in 96-well plates and cultured for 14 days [28] except FCS was substituted with FCS that had been charcoal-stripped to reduce the concentration of endogenous steroids. During the 14 day-culture, cells were treated with $10^{-8}, 10^{-9}, 10^{-10}$ or $10^{-11} \mathrm{M}$ DHT or vehicle, with six replicates per treatment group. At day 14, the cells were fixed and stained to determine osteoclast formation and resorptive activity as previously described [28].

\section{RNA Isolation and RT-PCR}

Total RNA isolated from mouse and human osteoclastlike cells, as well as mouse kidney, was extracted as described previously [29]. Contaminating genomic DNA was removed from RNA preparations by treatment with DNase (DNA-Free Kit; Ambion, USA) and cDNA synthesised using random hexamers and Moloney Murine Leukemia Virus reverse transcriptase (MMLV-RT) according to manufacturers' instructions. Primer sequences and conditions for RTPCR analyses are detailed in Table 1. Quantitative real-time PCR (Q-PCR) was performed in duplicate using 10ng cDNA per $25 \mu \mathrm{L}$ reaction on an Applied Biosystems 7500 Real Time PCR system, using Applied Biosystems Taqman gene expression assays ( 60 cycles of Q-PCR). A no template control was included in all Q-PCR reactions. Gene expression was determined using the $\Delta \Delta \mathrm{C}_{\mathrm{T}}$ method with $\mathrm{C}_{\mathrm{T}}$ values for the gene of interest normalized to $\beta$-actin, and expressed relative to a kidney positive control.

\section{Statistical Analyses}

The effect of DHT treatment on osteoclast formation and resorption area was analysed by one-way analysis of variance and specific differences were identified by Tukey's Post Hoc Test. A value of $P<0.05$ was considered significant. 
Table 1. Primer Sequences and Annealing Temperatures $\left(T_{A}\right)$ for RT-PCR of cDNA Isolated from Mouse and Human OsteoclastLike Cells In Vitro. Nucleotide Position Indicated for cDNA Sequence. Each Primer Pair Flanks an Intron/s

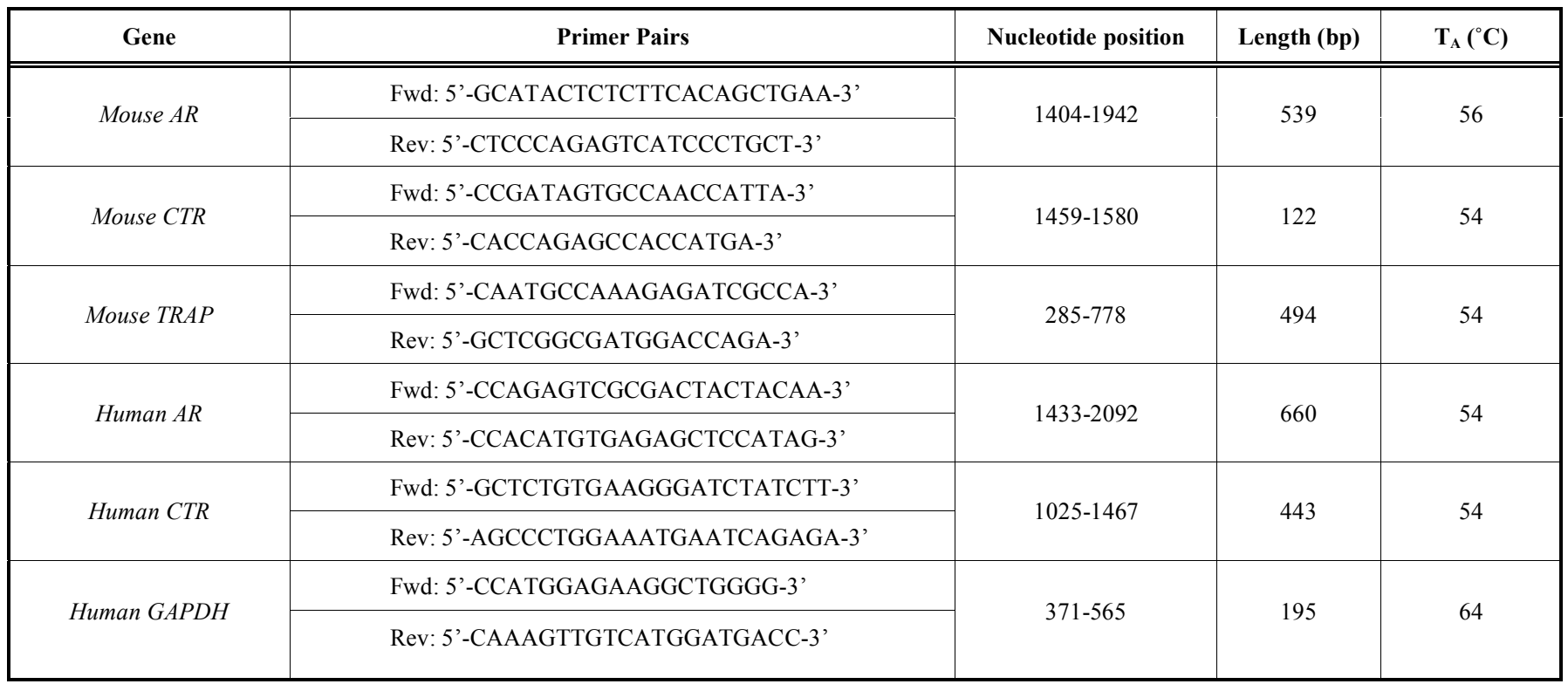

\section{RESULTS}

\section{AR mRNA and Protein Expression in Rat Bone}

We used in situ hybridisation and immunohistochemistry to detect expression of AR mRNA and protein respectively. Both AR mRNA and protein were detected in the testes and were predominantly located in the Sertoli cells and peritubular myoid cells (Fig. 1A, 1C). AR mRNA expression however, was not detected in any cell types within bone by in situ hybridisation (Fig. 1B). In contrast, expression of AR protein was detected by immunohistochemistry in the cytoplasm and nucleus of large, multinucleated cells found within resorption pits of trabecular bone (Fig. 2B, 2E). These cells were confirmed to be mature osteoclasts following staining of serial sections for TRAP activity (Fig. 2A, 2D) and CTR expression (Fig. 2C, 2F). AR protein was also observed in other bone cell types, such as osteocytes (Fig. 2B, 2E), osteoblasts and chondrocytes (data not shown) by immunohistochemistry.

\section{AR mRNA Expression in Osteoclast-Like Cells}

As we were unable to detect AR mRNA using in situ hybridisation in rat bone sections, we applied an in vitro approach of generating osteoclast-like cells from the bone marrows of wild-type mice, extracting RNA and performing RTPCR. After 7 days in culture large, multinucleated cells that stained positively for TRAP activity (referred to as mouse osteoclast-like cells) were generated (Fig. 3A, 3B). These cells were confirmed to be osteoclast-like cells as they expressed both TRAP and CTR mRNA (Fig. 3C). AR mRNA was also detected in in RNA isolated from 6 independent osteoclast-like cell cultures by Q-PCR (Fig. 3C). Having detected AR expression in mouse osteoclast-like cells, we extended these studies to address whether human osteoclastlike cells expressed AR mRNA. TRAP positive, CTR mRNA positive osteoclast-like cells derived from RANKL and M-CSF treatment of human cord blood mononuclear cells expressed AR mRNA (Fig. 4A).
Effect of Androgens on Osteoclastogenesis and Bone Resorption

The effect of androgens on osteoclast formation and function was investigated using human cord blood derived osteoclast-like cells grown on dentine. Osteoclast formation was assessed by counting the number of TRAP positive, multinucleated cells per dentine slice. The addition of DHT

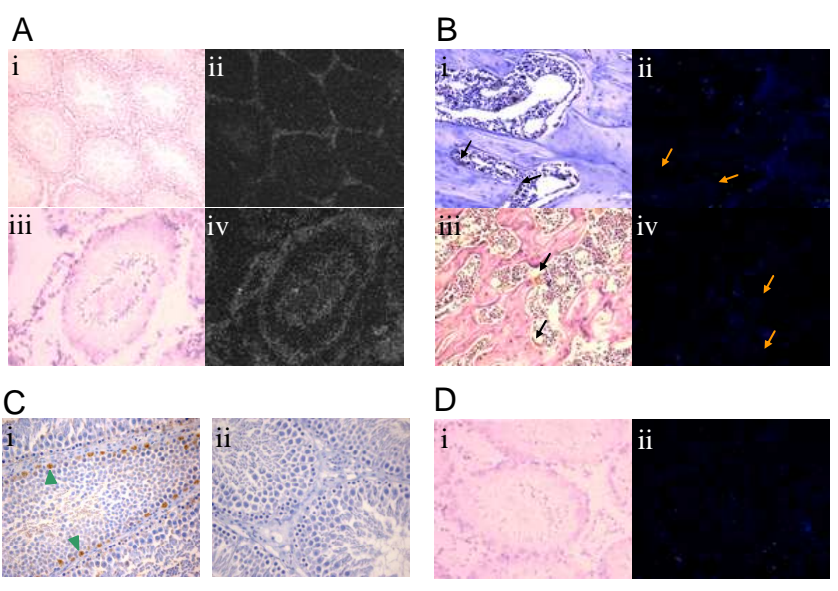

Fig. (1). AR mRNA and protein expression. All bright field sections are stained with haematoxylin. (A) Cellular localisation of AR mRNA by in situ hybridisation in rat testis. (i) brightfield, 100x; (ii) darkfield, 100x; (iii) brightfield, 200x; (iv) darkfield 200x. (B) (i and iii) Localisation of osteoclasts by CTR immunohistochemistry in rat femur, arrows indicate CTR positive osteoclasts (brown staining), 200x; (ii and iv) Cellular localisation of AR mRNA by in situ hybridisation in rat femur, serial sections of (i and iii) respectively, 200x. (C) Cellular localisation of AR protein by immunohistochemistry in rat testis. (i) AR protein (brown staining) in Sertoli cells (green arrowheads), 400x; (ii) immunohistochemistry negative control (no primary AR antibody), 400x. (D) In situ hybridisation negative control (AR sense probe) in testis sections. (i) brightfield, 200x; (ii) darkfield, 200x. 

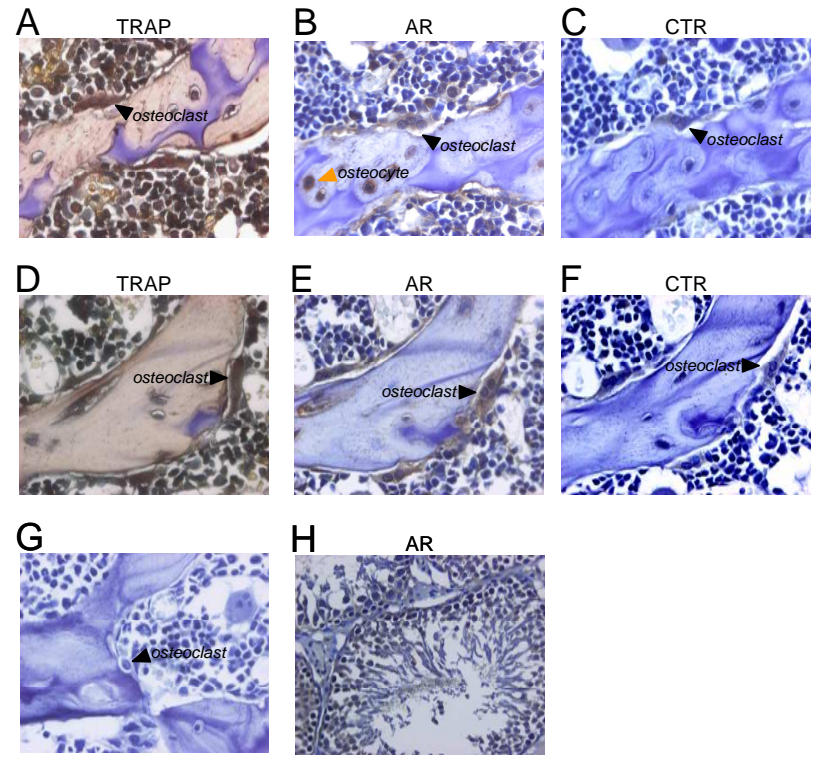

Fig. (2). Localisation of AR protein in rat femur sections. (A-C) and (D-F) represent serial sections respectively. $(\mathbf{B}, \mathbf{E})$ AR protein (brown staining) in multinucleated osteoclasts (arrowheads), and osteocytes (orange arrowhead). (A, D) TRAP (maroon staining) and $(\mathbf{C}, \mathbf{F})$ CTR protein (brown staining) in the same AR protein positive osteoclasts shown in $\mathbf{B}$ and $\mathbf{E}$. (G) Immunohistochemistry negative control (no primary antibody). (H) Immunohistochemistry AR positive (brown staining) control in rat testis. Original magnifications $(\mathrm{A}-\mathrm{G}) 400 \times,(\mathrm{H}) 200 \times$.

$\left(10^{-11} \mathrm{M}\right.$ to $\left.10^{-8} \mathrm{M}\right)$ to the culture medium did not affect the number of TRAP positive, multinucleated cells that formed (Fig. 4C). Similarly, DHT treatment did not affect the area of dentine that was resorbed by the osteoclast-like cells (Fig. 4D).

\section{DISCUSSION}

We have recently demonstrated that androgens act directly via the $\mathrm{AR}$ in osteoblasts to regulate bone resorption [12], but whether they have a direct action via the AR on osteoclasts remains to be determined. In vitro data suggest that androgens mediate their effects on osteoclast formation and function via direct activation of ARs in osteoclasts [13] or their progenitors $[14,15]$. However the data remain controversial and whether this mechanism of action is also true of osteoclasts in vivo, remains to be determined.

Many studies have reported that osteoclast precursors, osteoclasts or osteoclast-like cells express the $\operatorname{AR}[11,13$, 15, 16]. However some studies have defined osteoclasts on the basis of morphology alone [11], or have used osteoclast populations that were only $90 \%$ pure [13]. In the present study osteoclasts in situ were defined as multinucleated cells within resorption pits that stained positively for both TRAP activity and CTR expression, while osteoclast-like cells in vitro were assessed for TRAP activity and CTR mRNA.

The present work adds to the evidence that the AR protein is expressed by osteoclasts. Specifically, we performed immunohistochemistry on sections of rat femur to detect AR protein in osteoclasts as well as other bone cell types known to express the AR (i.e. osteoblasts, osteocytes, megakaryo-
A

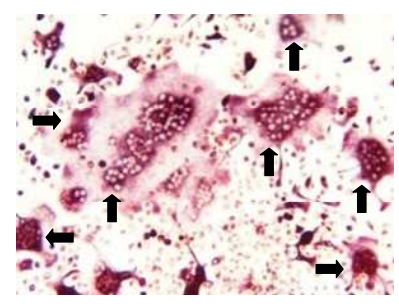

B

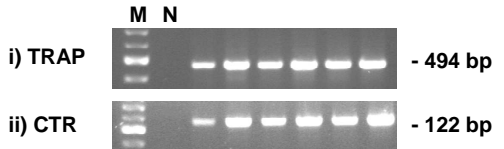

C

\begin{tabular}{|c|c|c|c|c|c|c|c|}
\hline & $\begin{array}{c}\text { OCL } \\
1\end{array}$ & $\begin{array}{c}\text { OCL } \\
2\end{array}$ & $\begin{array}{c}\text { OCL } \\
3\end{array}$ & $\begin{array}{c}\text { OCL } \\
4\end{array}$ & $\begin{array}{c}\text { OCL } \\
5\end{array}$ & $\begin{array}{c}\text { OCL } \\
6\end{array}$ & Kidney \\
\hline $\begin{array}{c}\text { AR mRNA } \\
\text { expression } \\
\text { (\% relative to } \\
\text { kidney) }\end{array}$ & 5.8 & 4.2 & 7.9 & 3.3 & 4.6 & 5.0 & 100 \\
\hline
\end{tabular}

Fig. (3). AR mRNA expression in mouse osteoclastlike cells in vitro. Wild-type mouse bone marrow extracts were treated for 3 days with $100 \mathrm{ng} / \mathrm{mL}$ MCSF, then a further 4 days with $100 \mathrm{ng} / \mathrm{mL}$ RANKL and 50ng/mL MCSF. (A) TRAP activity in mouse osteoclast-like cells. Arrows indicate multinucleated, TRAP positive osteoclast-like cells. Original magnification $200 \times$. (B) Six independent RNA isolations were performed on osteoclast-like cells. RNA was reverse transcribed to allow RT-PCR analysis of (i) mouse TRAP and (ii) mouse CTR mRNA. $\mathrm{M}=$ Molecular weight marker, N = PCR negative control. (C) Quantitative Real Time PCR analysis of AR expression in mouse osteoclast-like cells was performed in duplicate on the six cDNA preparations derived from the osteoclast-like cells (OCL 1-6) described in B), as well as cDNA derived from a wild-type mouse kidney. Gene expression was determined using the DDCT method with CT values for AR normalized to $\beta$-actin, and expressed as a percentage relative to the kidney positive control.

cytes $[9-11,30])$. We were unable however, to detect AR mRNA expression in bone cells of the rat femur using in situ hybridisation This is most likely due to the sensitivity of the assay as AR mRNA was detected by in situ hybridisation in the positive control tissue, the testes, which is known to express high levels of AR mRNA while in contrast, the level of AR mRNA in bone is much lower [31].

To further investigate the role of androgens acting via the AR in osteoclasts, we employed an in vitro system. The advantage of this approach was that a more pure population of osteoclast cells, that did not require co-culture with osteoblasts or stromal cells that are known to express the AR $[11,32]$. The cells produced are termed "osteoclast-like" because they exhibit many of the characteristics of osteoclasts in vivo, such as expression of osteoclast markers (eg., TRAP enzyme activity and CTR protein) and the ability to form resorption pits on calcified substrates such as dentine. We were able to show expression of AR mRNA in osteoclast-like cells derived from both mouse bone marrow and human cord blood.

We then used the human osteoclast-like cells to test whether androgens could affect osteoclast formation and 


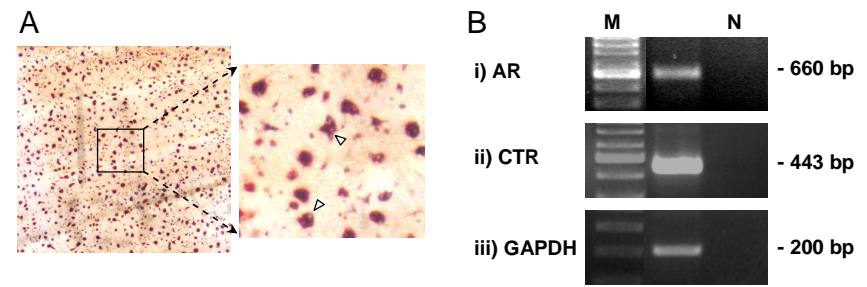

C

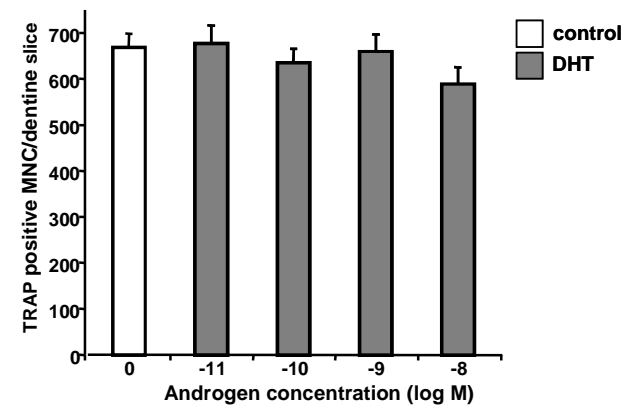

D

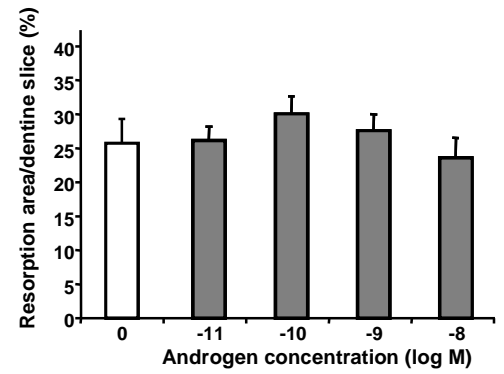

Fig. (4). Effect of DHT treatment on the formation and activity of human osteoclast-like cells. (A) TRAP stained human osteoclastlike cells cultured on dentine slices. White arrowheads indicate multinucleated cells. (B) RT-PCR analysis of cDNA derived from human osteoclast-like cells using primers for (i) human AR, (ii) human CTR and (iii) human GAPDH. M = DNA size standard, $\mathrm{N}$ $=$ PCR negative control. (C) Effect of DHT treatment on osteoclastogenesis in vitro, expressed as the number of TRAP positive multinucleated cells (MNC) per dentine slice. (D) Effect of DHT treatment on osteoclastic bone resorption in vitro. Values are mean $\pm \mathrm{SEM}, \mathrm{n} \geq 6$.

function in vitro. We have used this approach previously to successfully demonstrate modulation of osteoclast formation and activity [33]. Despite expressing the AR, there was no effect of the non-aromatisable androgen, DHT on the formation or function of the human osteoclast-like cells in vitro. Therefore these findings do not support the hypothesis that androgens act directly on osteoclasts via the AR to regulate their formation or resorptive activity. An alternate view is that the action of androgens on osteoclasts is mediated indirectly by the AR in stromal cells and/or osteoblasts. We have previously demonstrated that specific deletion of the AR in mature osteoblasts results in increased bone resorption in male mice [12]. This increased bone resorption in osteoblastspecific ARKO mice may, at least in part, be mediated by osteoprotegerin (OPG), a potent inhibitor of osteoclastogenesis [34] as OPG mRNA expression is increased by androgens [35]. Androgens have also been shown to inhibit the production of IL- 6 in murine bone marrow stromal cells, an essential mediator of bone loss in estrogen deficiency [36].
Furthermore, Kawano et al. [37] have shown that RANKL mRNA expression is upregulated in cultured primary osteoblasts derived from global ARKO male mice, suggesting that the role of androgens is to inhibit osteoclast formation and subsequent bone resorption via its suppression of RANKL expression in osteoblasts. This may also explain, at least in part, the conflicting data regarding the effect of androgens in previous studies which used a mixed population of bone cells $[13,17,19]$. In contrast, preliminary data published in abstract form from a mouse model in which the AR is deleted specifically within osteoclasts suggest that androgens can act directly via the AR in osteoclasts. Osteoclastspecific ARKO male mice exhibit trabecular bone loss due to increased osteoclastogenesis and bone resorption [38]. Complete characterisation of the osteoclast-specific ARKOs may advance our understanding of the role of androgens in osteoclastic bone resorption.

In summary, we have demonstrated that osteoclasts within the rat femur express AR protein in situ, and that human and mouse osteoclast-like cells, express AR mRNA in vitro. DHT treatment however, of human osteoclast-like cells had no effect on osteoclast formation or resorptive function in vitro, thereby supporting the hypothesis that the actions of androgens on bone resorption require the presence of other bone cells such as osteoblasts or are mediated indirectly via the AR in stromal cells and/or osteoblasts.

\section{ACKNOWLEDGEMENTS}

The authors would like to thank Drs Julie McManus and Helen MacLean for expert advice and helpful discussions. This study was supported by The National Health and Medical Research Council (Project Grant ID: 350346), The Cass Foundation Ltd., Sir Edward Dunlop Medical Research Foundation, The Austin Hospital Medical Research Foundation, an Endocrine Research Grant provided by Eli Lilly Australia and an Eva and Les Erdi Major Research Grant. Amanda Notini was supported by an Australian Postgraduate Award.

\section{REFERENCES}

[1] Francis RM, Peacock M, Aaron JE, et al. Osteoporosis in hypogonadal men: role of decreased plasma 1,25-dihydroxyvitamin $\mathrm{D}$, calcium malabsorption, and low bone formation. Bone 1986; 7(4): 261-8.

[2] Gunness M, Orwoll E. Early induction of alterations in cancellous and cortical bone histology after orchiectomy in mature rats. J Bone Miner Res 1995; 10(11): 1735-44.

[3] Vanderschueren D, Van Herck E, Suiker AM, Visser WJ, Schot LP, Bouillon R. Bone and mineral metabolism in aged male rats: short and long term effects of androgen deficiency. Endocrinology 1992; 130(5): 2906-16

[4] Riggs BL, Khosla S, Melton LJ, 3rd. Primary osteoporosis in men: role of sex steroid deficiency. Mayo Clin Proc 2000; (Suppl 75): S46-50.

[5] Wakley GK, Schutte HD, Jr, Hannon KS, Turner RT. Androgen treatment prevents loss of cancellous bone in the orchidectomized rat. J Bone Miner Res 1991; 6(4): 325-30.

[6] Colvard DS, Eriksen EF, Keeting PE, et al. Identification of androgen receptors in normal human osteoblast-like cells. Proc Natl Acad Sci USA 1989; 86(3): 854-7.

[7] Benz DJ, Haussler MR, Thomas MA, Speelman B, Komm BS High-affinity androgen binding and androgenic regulation of alpha 1(I)-procollagen and transforming growth factor-beta steady state messenger ribonucleic acid levels in human osteoblast-like osteosarcoma cells. Endocrinology 1991; 128(6): 2723-30. 
[8] Wiren K, Keenan E, Zhang X, Ramsey B, Orwoll E. Homologous androgen receptor up-regulation in osteoblastic cells may be associated with enhanced functional androgen responsiveness. Endocrinology 1999; 140(7): 3114-24.

[9] Abu EO, Horner A, Kusec V, Triffitt JT, Compston JE. The localization of androgen receptors in human bone. J Clin Endocrinol Metab 1997; 82(10): 3493-7.

[10] Noble B, Routledge J, Stevens H, Hughes I, Jacobson W. Androgen receptors in bone-forming tissue. Horm Res 1999; 51(1): 31-6.

[11] van der Eerden BC, van Til NP, Brinkmann AO, Lowik CW, Wit $\mathrm{JM}$, Karperien M. Gender differences in expression of androgen receptor in tibial growth plate and metaphyseal bone of the rat. Bone 2002; 30(6): 891-6.

[12] Notini AJ, McManus JF, Moore A, et al. Osteoblast deletion of exon 3 of the androgen receptor gene results in trabecular bone loss in adult male mice. J Bone Miner Res 2007; 22(3): 347-56.

[13] Pederson L, Kremer M, Judd J, et al. Androgens regulate bone resorption activity of isolated osteoclasts in vitro. Proc Natl Acad Sci USA 1999; 96(2): 505-10.

[14] Michael H, Harkonen PL, Vaananen HK, Hentunen TA. Estrogen and testosterone use different cellular pathways to inhibit osteoclastogenesis and bone resorption. J Bone Miner Res 2005; 20(12): 2224-32.

[15] Huber DM, Bendixen AC, Pathrose P, et al. Androgens suppress osteoclast formation induced by RANKL and macrophage-colony stimulating factor. Endocrinology 2001; 142(9): 3800-8.

[16] Mizuno Y, Hosoi T, Inoue S, et al. Immunocytochemical identification of androgen receptor in mouse osteoclast-like multinucleated cells. Calcif Tissue Int 1994; 54(4): 325-6.

[17] Tobias JH, Chambers TJ. The effect of sex hormones on bone resorption by rat osteoclasts. Acta Endocrinol (Copenh) 1991; 124(1): 121-7.

[18] Caputo CB, Meadows D, Raisz LG. Failure of estrogens and androgens to inhibit bone resorption in tissue culture. Endocrinology 1976; 98(4): 1065-8

[19] Chen Q, Kaji H, Sugimoto T, Chihara K. Testosterone inhibits osteoclast formation stimulated by parathyroid hormone through androgen receptor. FEBS Lett 2001; 491(1-2): 91-3.

[20] Lindsay R, Hart DM, Aitken JM, MacDonald EB, Anderson JB, Clarke AC. Long-term prevention of postmenopausal osteoporosis by oestrogen. Evidence for an increased bone mass after delayed onset of oestrogen treatment. Lancet 1976; 1(7968): 1038-41.

[21] Wronski TJ, Cintron M, Doherty AL, Dann LM. Estrogen treatment prevents osteopenia and depresses bone turnover in ovariectomized rats. Endocrinology 1988; 123(2): 681-6.

[22] Quinn JM, Morfis M, Lam MH, et al. Calcitonin receptor antibodies in the identification of osteoclasts. Bone 1999; 25(1): 1-8.

[23] Takeda H, Chang C. Immunohistochemical and in-situ hybridization analysis of androgen receptor expression during the development of the mouse prostate gland. J Endocrinol 1991; 129(1): 83-9.
[24] Candido R, Jandeleit-Dahm KA, Cao Z, et al. Prevention of accelerated atherosclerosis by angiotensin-converting enzyme inhibition in diabetic apolipoprotein E-deficient mice. Circulation 2002; 106(2): 246-53.

[25] Kovacs CS, Chafe LL, Woodland ML, McDonald KR, Fudge NJ, Wookey PJ. Calcitropic gene expression suggests a role for the intraplacental yolk sac in maternal-fetal calcium exchange. Am J Physiol Endocrinol Metab 2002; 282(3): E721-32.

[26] Kask K, Jerecic J, Zamanillo D, Wilbertz J, Sprengel R, Seeburg $\mathrm{PH}$. Developmental profile of kainate receptor subunit KA1 revealed by Cre expression in YAC transgenic mice. Brain Res 2000; 876(1-2): 55-61.

[27] Itoh K, Udagawa N, Katagiri T, et al. Bone morphogenetic protein 2 stimulates osteoclast differentiation and survival supported by receptor activator of nuclear factor-kappaB ligand. Endocrinology 2001; 142(8): 3656-62.

[28] Hodge JM, Kirkland MA, Aitken CJ, et al. Osteoclastic potential of human CFU-GM: biphasic effect of GM-CSF. J Bone Miner Res 2004; 19(2): 190-9.

[29] Chomczynski P, Sacchi N. Single-step method of RNA isolation by acid guanidinium thiocyanate-phenol-chloroform extraction. Anal Biochem 1987; 162(1): 156-9.

[30] Khetawat G, Faraday N, Nealen ML, et al. Human megakaryocytes and platelets contain the estrogen receptor beta and androgen receptor (AR): testosterone regulates AR expression. Blood 2000; 95(7): 2289-96.

[31] Bookout AL, Mangelsdorf DJ. A quantitative real-time PCR protocol for analysis of nuclear receptor signaling pathways. Nucl Recept Signal (www.nursa.org) 2003; 1: eo12.

[32] Mantalaris A, Panoskaltsis N, Sakai Y, et al. Localization of androgen receptor expression in human bone marrow. J Pathol 2001; 193(3): 361-6.

[33] Holloway WR, Collier FM, Aitken CJ, et al. Leptin inhibits osteoclast generation. J Bone Miner Res 2002; 17(2): 200-9.

[34] Simonet WS, Lacey DL, Dunstan CR, et al. Osteoprotegerin: a novel secreted protein involved in the regulation of bone density. Cell 1997; 89(2): 309-19.

[35] Chen Q, Kaji H, Kanatani M, Sugimoto T, Chihara K. Testosterone increases osteoprotegerin mRNA expression in mouse osteoblast cells. Horm Metab Res 2004; 36(10): 674-8.

[36] Bellido T, Jilka RL, Boyce BF, et al. Regulation of interleukin-6, osteoclastogenesis, and bone mass by androgens. The role of the androgen receptor. J Clin Invest 1995; 95(6): 2886-95.

[37] Kawano H, Sato T, Yamada T, et al. Suppressive function of androgen receptor in bone resorption. Proc Natl Acad Sci USA 2003 100(16): 9416-21.

[38] Nakamura T, Watanabe T, Nakamichi Y, et al. Genetic evidence of androgen receptor function in osteoclasts. J Bone Miner Res 2005; 20(Suppl 1): S104.

(C) Turner et al.; Licensee Bentham Open.

This is an open access article licensed under the terms of the Creative Commons Attribution Non-Commercial License (http://creativecommons.org/licenses/by-nc/3.0/) which permits unrestricted, non-commercial use, distribution and reproduction in any medium, provided the work is properly cited. 